\title{
CSP-Biogas Combined Microgrid System for Rural and Remote Areas of Bangladesh
}

\author{
Atiqur Rahman, Miftah Al Karim \\ Department of Electrical and Electronic Engineering, American International University-Bangladesh (AIUB), Dhaka, Bangladesh
}

Email address:

atiqur160@gmail.com (A. Rahman),miftah.aiub@gmail.com (M. A. Karim)

\section{To cite this article:}

Atiqur Rahman, Miftah Al Karim. CSP-Biogas Combined Microgrid System for Rural and Remote Areas of Bangladesh. American Journal of Electrical Power and Energy Systems. Vol. 4, No. 5, 2015, pp. 71-76. doi: 10.11648/j.epes.20150405.12

\begin{abstract}
Power plays a vital role for a developing country like Bangladesh. Like the rest of the countries of the world, the demand of power is rising day by day in our country. But Bangladesh has been facing electricity shortage for many years. In our country, a major portion of total population still does not have the access to electricity. For becoming a developed country, Bangladesh has to overcome the problem of power crisis. Renewable energy can be a great source to solve this problem. Already some government and non-government organization are working on renewable sources like solar energy, bioenergy, wind energy, etc. In this paper we mainly focused to develop and implement microgrid system with CSP-biogas combined power plant for providing electricity in rural and remote areas of Bangladesh.
\end{abstract}

Keywords: Concentrating Solar Power, Heat Transfer Fluid, Concentrating Solar Power with Biogas Plant, Collectors

\section{Introduction}

Energy is a key to socio economic development of any country. Bangladesh is a small country of $1,47,570$ square kilometers having more than 160 million people would require gigantic amount for its development. Nowadays almost 59.6 percent of Bangladeshi people are under the connection of the electricity power grid that means 41.4 percent people are does not access to power grid connection. The power supply is not sufficient to meet the peak demand in Bangladesh. In rural areas, only about 42 percent populations have grid electricity connection where about 58 percent of that out of grid connection [1]. Rural Electrification Board in Bangladesh (REB) provides electricity connection in many rural areas. Every year about 40000 new consumers are access to electricity; it would take about 40 years to provide electricity connection for all people in Bangladesh [2]. Many rural people who live in isolated areas, they are totally out of grid connection. This paper set to develop and implement the initiative step. Bangladesh is one of the sunniest parts of the world [3]. CSP-biogas combined power plant will be a best solution for isolated area of Bangladesh.

\section{Concentrating Solar Power (CSP)}

Concentrated Solar Power (CSP) is a technology which produces electricity by using mirrors or lenses to concentrate a large area of sunlight into a small area. In this system the concentrated light is converted to heat, which produces steam. Then stream drive a stream turbine that connected to an electric power generator. CSP are most promising system for microgrid application. CSP utilizes three technological approaches: Parabolic solar collectors systems, Power tower system and Dish engine systems.

\subsection{Parabolic Trough System}

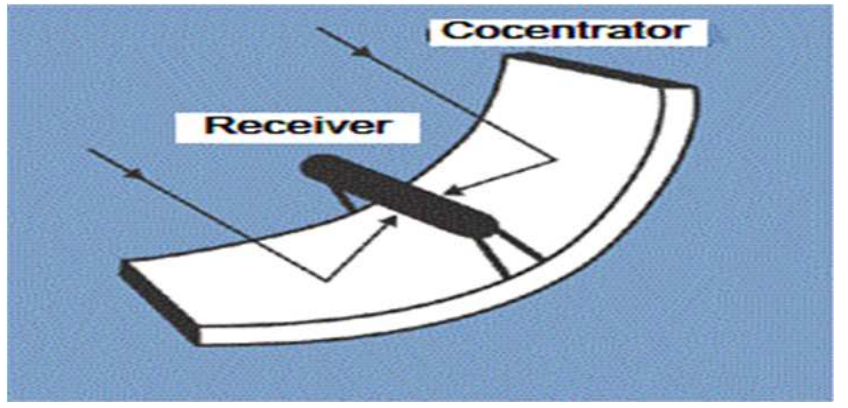

Figure 1. Parabolic through system.

These types of solar concentrators use large U-shaped reflectors. It contains oil filled pipes that running along their central point. The focus sunlight heats the oil inside the pipes. The hot oil, which make steam that run conventional steam 
turbines and generator. Fig. 1 shows the parabolic trough system.

\subsection{Power Tower System}

Power tower system is called a central receiver system. In this systems concentrate sunlight focus on a central receiver on top of a tower. The receiver contains a fluid deposit. The working fluid in the receiver is heated with high temperature. The hot fluid can be used to make steam for generation of electricity and stored for later use. So power tower systems can be produce electricity during peak periods on cloudy days or few hours after sunset. Fig. 2 shows the power tower system.

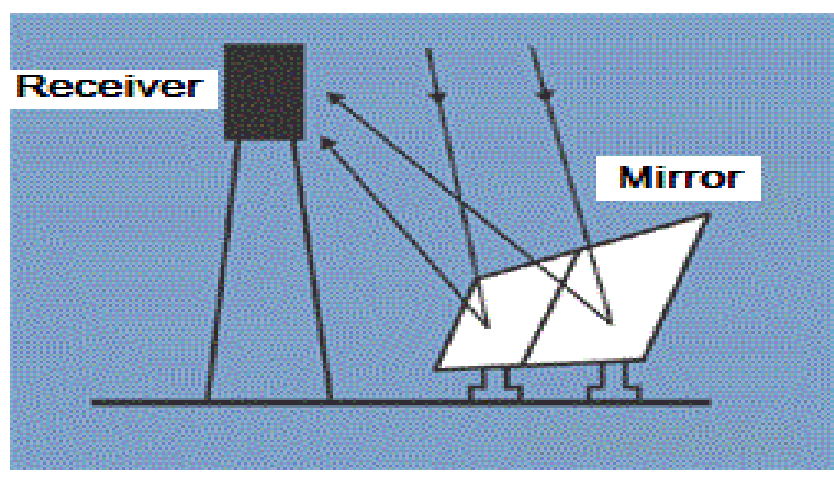

Figure 2. Power tower system.

\subsection{Dish Sterling System}

Dish sterling system use mirrored dishes to focus and concentrate light onto a receiver. The receiver embeds at the central point of the dish. The receiver is compact into an external combustion engine. The engine has thin tube that contains hydrogen or helium gas. Fig. 3 shows the dish sterling system.

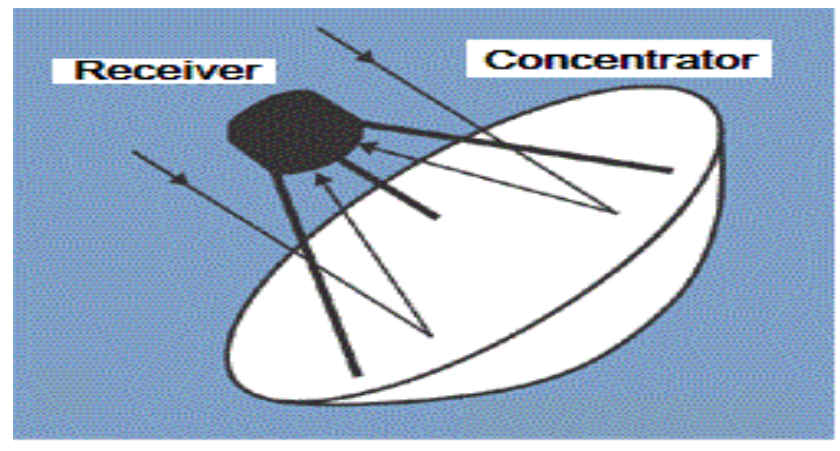

Figure 3. Dish sterling system.

When concentrated light falls on the receiver, it heats the gas inside the tubes with very high temperature, which causes hot gas to expand inside the cylinder. This expanding gas runs the pistons. The piston rotates a crankshaft. Then crankshaft drives an electric generator.

\section{Biogas}

Biogas is an anaerobic digester that produces from organic matter by a consortium of bacteria. Biogas is mixture of methane (CH4), carbon dioxide (CO2), hydrogen sulphide (H2S) and varying quantities of water. Methane is the most valuable component. Natural gas consists of $80 \%-90 \%$ methane. Biogas can produce $55 \%-75 \%$ methane which can be increased to $80 \%-90 \%$ with free liquid [4]. Biogas can be used for heating, electricity production and many other operations.

\section{Profile of Thanchi}

For research purpose, a survey was done in a remote upazila Thanchi in the district of Bandarban. It is located at $21.78621^{\circ} \mathrm{N} 92.4278^{\circ} \mathrm{E}$. Thanchi is located about $85 \mathrm{~km}$ away from Bandarban city. Total area of Thanchi is about 1020.82 sq.km. There are 4 unions and 178 villages in Thanchi. Total population of thanchi is about 27586. Population density of Thanchi is 27 per sq.km [5]. Thanchi is one of the most remote areas of Bangladesh. There are no electricity connections in Thanchi. The nearest grid electricity line is about 34 kilometers far from Thanchi. People need to alternative solution for energy, such as firewood and oil lamp. Now a few numbers of people are using solar home system and some diesel generators are using to serve electricity for only bazaar areas. All the diesel generators are runs from $6 \mathrm{pm}$ to $10 \mathrm{pm}$. There is no biogas plant in Thanchi. There is a small river named sangu. It contains small amount of water over the year. So micro hydro is not possible at this area. The average air temperature is $24.10 \mathrm{c}$. Wind speed is around $2.9 \mathrm{~m} / \mathrm{s}$ which is not possible to run the micro wind generator, finally it can't be installed at that area. Daily radiation of sun in Thanchi is about $4.69 \mathrm{KWh} / \mathrm{m} 2 / \mathrm{c}$ which is good for running CSP plant.

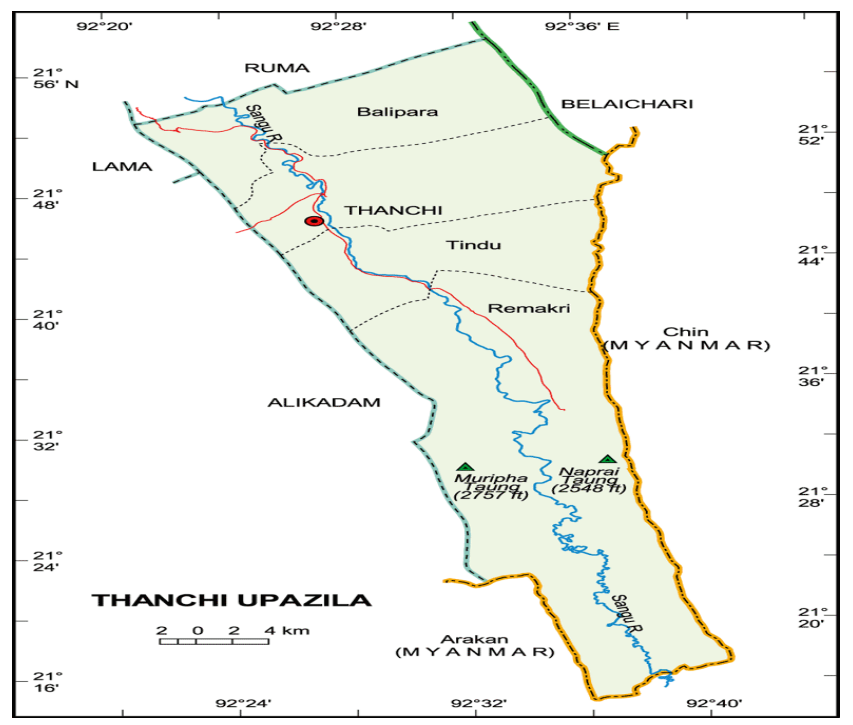

Figure 4. The area map of Thanchi. 
Table 1. Weather information of Thanchi [6].

\begin{tabular}{|c|c|c|c|c|c|c|c|c|}
\hline Month & $\begin{array}{l}\text { Air } \\
\text { temperature }{ }^{\circ} \mathbf{c}\end{array}$ & $\begin{array}{l}\text { Relative } \\
\text { Humidity \% }\end{array}$ & $\begin{array}{l}\text { Daily adiation } \\
\text { horizontal } \\
\mathrm{KWh} / \mathbf{m}^{2} / c\end{array}$ & $\begin{array}{l}\text { Atmospheric } \\
\text { pressure in } \\
\mathrm{Hg}\left(0^{\circ} \mathrm{c}\right)\end{array}$ & Wind speed /s & $\begin{array}{l}\text { Earth } \\
\text { temperature }{ }^{\circ} \mathrm{c}\end{array}$ & $\begin{array}{l}\text { Heating } \\
\text { degree-days } \\
18^{\circ} \mathrm{c}\end{array}$ & $\begin{array}{l}\text { Cooling } \\
\text { degree-days } \\
10^{\circ} \mathrm{c}\end{array}$ \\
\hline January & 19.1 & 52.7 & 4.80 & 29.1 & 2.5 & 18.9 & 0 & 282 \\
\hline February & 21.6 & 53.0 & 5.32 & 29.1 & 2.6 & 22.2 & 0 & 325 \\
\hline March & 24.5 & 58.5 & 5.84 & 29.0 & 2.7 & 26.4 & 0 & 451 \\
\hline April & 26.0 & 68.2 & 5.92 & 29.0 & 2.7 & 28.0 & 0 & 479 \\
\hline May & 26.4 & 77.2 & 5.31 & 28.9 & 2.8 & 28.1 & 0 & 510 \\
\hline June & 26.4 & 85.6 & 3.86 & 28.8 & 4.0 & 26.9 & 0 & 491 \\
\hline July & 26.0 & 87.1 & 3.81 & 28.8 & 4.0 & 26.3 & 0 & 496 \\
\hline August & 26.0 & 86.3 & 3.95 & 28.9 & 3.6 & 26.4 & 0 & 495 \\
\hline September & 25.7 & 84.4 & 4.25 & 28.9 & 2.8 & 26.0 & 0 & 471 \\
\hline October & 25.0 & 78.5 & 4.40 & 29.0 & 2.2 & 25.0 & 0 & 466 \\
\hline November & 22.7 & 69.8 & 4.34 & 29.1 & 2.3 & 22.3 & 0 & 382 \\
\hline December & 20.0 & 59.3 & 4.48 & 29.1 & 2.3 & 19.4 & 0 & 309 \\
\hline Annual & 24.1 & 71.8 & 4.69 & 29.0 & 2.9 & 24.7 & 0 & 5157 \\
\hline
\end{tabular}

\section{Livestock Population of Thanchi}

Total number of cows and buffaloes 5649, total number of goats 2628 , total number of sheep 167 , total number of hens 20081, total number of ducks 625 in Thanchi [7].

Table 2. Total livestock in Thanchi.

\begin{tabular}{ll}
\hline Species & Number \\
\hline Cow\&buffalo & 5649 \\
Goat & 2628 \\
Sheep & 167 \\
Hen & 20081 \\
Duck & 625 \\
Total & 29150 \\
\hline
\end{tabular}

Table 3. Load calculation of Thanchi.

\begin{tabular}{lll}
\hline Load type & Kilowatt(Kw) & $\begin{array}{l}\text { Megawatt } \\
\text { hour per day } \\
\text { (Mwh/d) }\end{array}$ \\
\hline Total load for house & 1003.632 & 11.868 \\
Total load for school & 17.70 & 0.1416 \\
Total load for shop & 5.34 & 0.0772 \\
Total load for hospital & 0.89 & 0.00187 \\
$\begin{array}{l}\text { Total load for BGB and police } \\
\text { station }\end{array}$ & 2.225 & 0.02835 \\
Total load of Thanchi & 1029.787 & 12.117 \\
\hline
\end{tabular}

\section{Load Assumption of Thanchi}

For designing a CSP-biogas combined system first task is to determine the approximate load that will be connected to the system. Each and every part of the CSP-biogas plant system will be designed according to the load requirement. There is 4872 house in Thanchi. Average members of each house are 4.73. In Thanchi there are 14 government primary school, 2 registered primary school, 22 non registered primary school, 77 NGO school, 2 government secondary school, 1 non-government secondary school, 4 BGB camp, 1 community health centre and 2 bazaar with 50 shops. In an average 4 pieces bulb and 2 fans are enough for each an every house at Thanchi. All bulbs are 14 watt energy saving bulb and fans are 75 watt. Each bulb will runs 6 hours per day and fan will runs 14 hours per day. All school will run 2 fans 8 hours per day. Each shop will runs 2 bulbs 5 hours and 1 fan 15 hours per day. In hospital 10 fans will run 24 hours and 10 bulbs will run 5 hour. Each BGB camp 5 fans will runs 14 hour and 5 bulbs will run 6 hours per day.

\section{Proposed CSP-Biogas Power Plant}

For the supplying of electricity in Thanchi we proposed some small scale CSP plant and some biogas power plant. Here we have considered some 60KW CSP plant and some $20 \mathrm{KW}$ biogas power plant. Then run CSP and biogas together for making combined power plant. Thanchi is a hilly area so firstly we have to select some plane area for installation CSP plant. For installation of biogas power plant we have to select some density area where number of cows is enough to run this type of power plant.

\subsection{KW CSP Plant}

The system used here includes parabolic trough collectors and an organic rankine cycle (ORC). This system has a storage system. For developing $60 \mathrm{KW}$ small scale plant, at first a steam engine has been considered. This steam engine needs to supply superheated steam that temperature is more than $300^{\circ} \mathrm{c}$. Instead an ORC in the right power range which need only an inlet temperature of about $170^{\circ} \mathrm{c}$. In this system 3 parallel collector rows and 12 rows in series collector have been selected [8]. Each collector with an aperture width of $2.37 \mathrm{~m}$ and length of 5.95 , that total of $428.4 \mathrm{~m}$ for the 12 collectors with a distance about $7.2 \mathrm{~m}$. The absorber pipe diameter is about $38.4 \mathrm{~mm}$ [9]. For installation of a $60 \mathrm{KW}$ CSP plant a ground of $27000 \mathrm{~m}^{2}$ is needed.

\subsection{KW Biogas Power Plant}

Biogas can be converted directly into electricity using a fuel cell or by using combustion engine. Generally combustion engine are more useful for biogas power 
generation. The combustion engine used biogas as fuel.

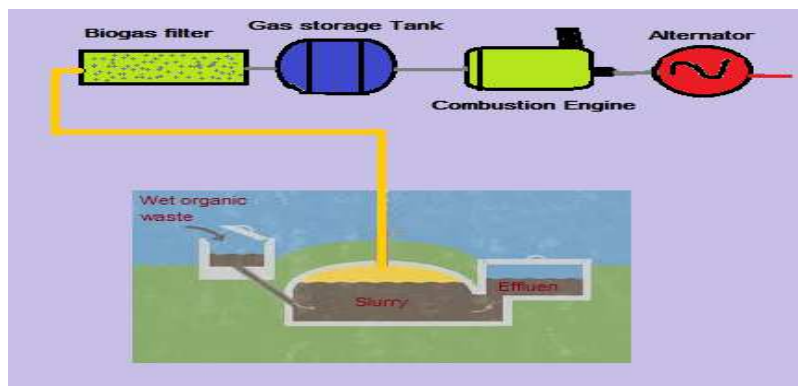

Figure 5. Biogas power plant.

In this system at first organic matter mixed with an equal quantity of water in mixing tank. That called slurry. Then slurry is feed into the digester through the inlet chamber. Then digester produces biogas. After filtering of this biogas it store in a gas storage tank. This gas storage tank supply biogas as fuel to combustion engine. The combustion engine run a generator and produces electricity. For running of a $20 \mathrm{KW}$ biogas power plant $18700 \mathrm{~L}$ methane is needed [10]. One cow that can produce up to 250L methane [11]. So 75 cow enough for a $20 \mathrm{KW}$ biogas power plant. This type of power plant can produce $320 \mathrm{KWh}$ of electricity.

\section{Microgrid Design for Thanchi}

Thanchi is a hilly area so it is very difficult to buildup and maintains the grid connection. For hilly area the cost of transmission line is also very high. Table 4 shows the cost of transmission line.

Table 4. Cost of transmission line [12].

\begin{tabular}{lll}
\hline \multirow{2}{*}{ Voltage level } & \multicolumn{2}{c}{ Cost per km (USD) } \\
\cline { 2 - 3 } & Flat surfaces & Hilly areas \\
\hline $11 \mathrm{KV}$ & 3200 & 5600 \\
$33 \mathrm{KV}$ & 11200 & 16000 \\
$66 \mathrm{KV}$ & 25600 & 38400 \\
$132 \mathrm{KV}$ & 32000 & 44000 \\
\hline
\end{tabular}

Main grid connection is far away from Thanchi. In Bangladesh generally $132 \mathrm{KV}$ transmission line is used for long distance transmission of electricity. Table 5 shows the distance from nearest grid and transmission line cost for four union of Thanchi.

Table 5. Distance from nearest grid of Thanchi and its cost [13].

\begin{tabular}{lll}
\hline Name of union & $\begin{array}{l}\text { Distance from } \\
\text { nearest grid }(\mathbf{k m})\end{array}$ & $\begin{array}{l}\text { Cost for 132KV line } \\
\text { (USD) }\end{array}$ \\
\hline Balipara & 34 & 1496000 \\
Thanchi Sadar & 52 & 2288000 \\
Tindu & 64 & 2816000 \\
Remakri & 77 & 3388000 \\
\hline
\end{tabular}

Microgrid can be a great solution for supplying electricity in Thanchi. Single microgrid is also difficult and costly for this area. So five individual microgrid systems are proposed for removing of this problem. Those five microgrid can be covered about $90 \%$ of total population. Fig. 6 shows the energy consumption of five microgrid systems.

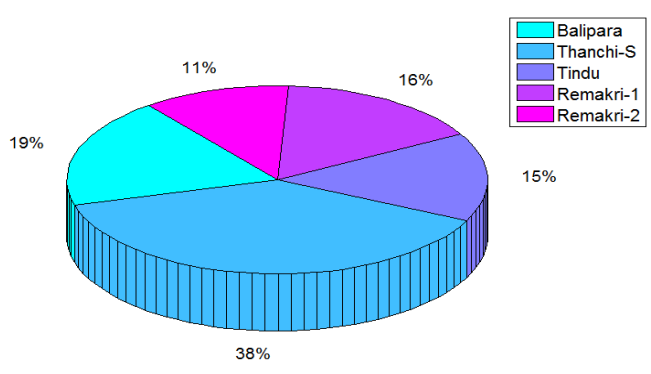

Figure 6. Energy consumption of Thanchi.

\subsection{Microgrid Connection Design for Balipara Region}

Total population of Balipara is about 5447.There are 56 school and one bazaar in Balipara. This microgrid design can cover about 4500 people. The primary load for Balipara is 2.76 MWh/d and $207.47 \mathrm{KW}$ peak. Each CSP plant is $60 \mathrm{KW}$ and biogas power plant is $20 \mathrm{KW}$.

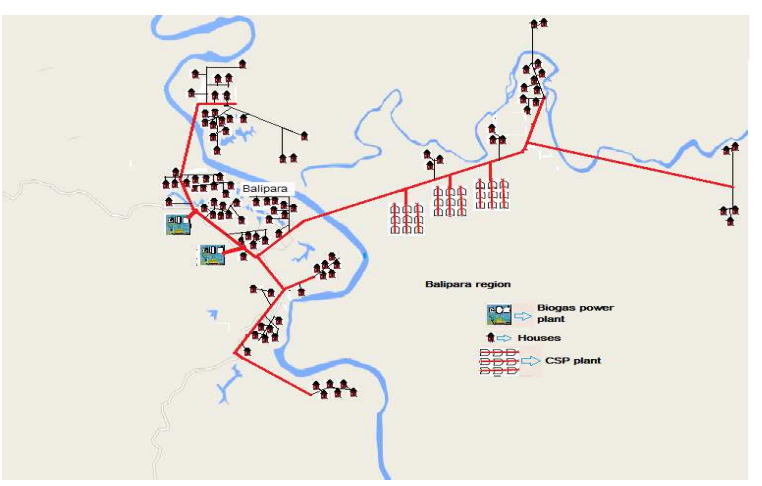

Figure 7. Microgrid design of Balipara region.

For $207 \mathrm{KW}$ power supplies three CSP and two biogas power plant have to be considered. Here each house in the design is considered equal to 15 actual houses.

\subsection{Microgrid Connection Design for Thanchi Region}

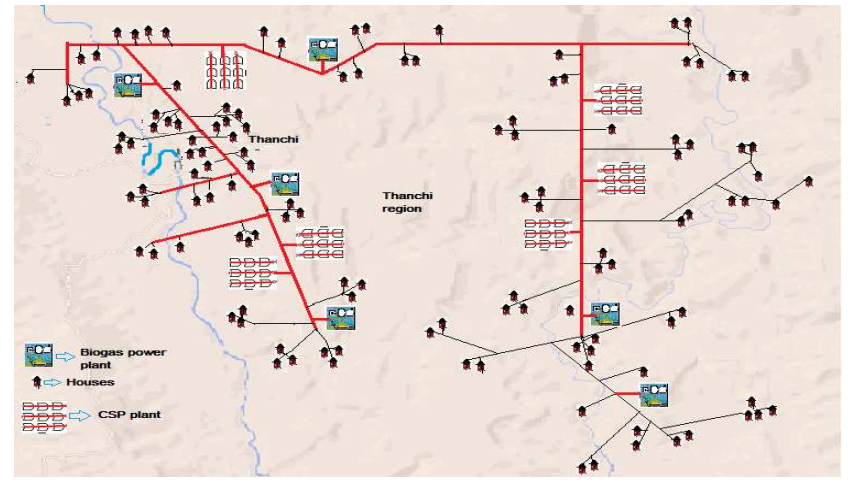

Figure 8. Microgrid design of Thanchi region.

Total population of Thanchi sadar union is about 8040.It contains six schools, one hospital, one police station and one BGB camp. Microgrid system of Thanchi region can cover total 7500 people of Thanchi and also can cover 3000 people of Tindu and 300 people of Balipara. Load of this region 
about $5.581 \mathrm{MWh} / \mathrm{d}$ and $473.039 \mathrm{KW}$ peak. For $473.039 \mathrm{KW}$ power supplies six CSP plant and six biogas power plant have to be considered.

\subsection{Microgrid Connection Design for Tindu Region}

Total population of Tindu union is about 7800.Tindu has only one primary school. Microgrid system of Tindu region can cover total 4300 people. Total primary load of this region is about $2.22 \mathrm{MWh} / \mathrm{d}$ and $187.42 \mathrm{KW}$ peak. For $187.42 \mathrm{KW}$ power supplies three CSP and one biogas power plant have to be considered.

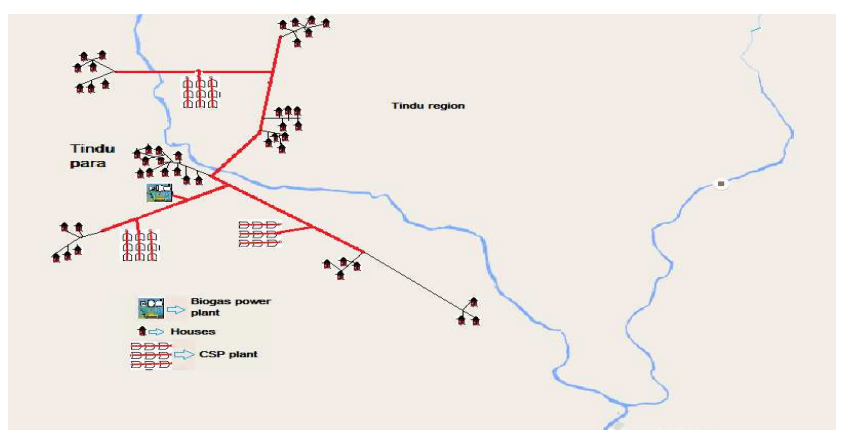

Figure 9. Microgrid design of Tindu region.

\subsection{Microgrid Connection Design for Remakri Region-1}

Total population of Remakri union is about 7800.It has three school and one BGB camp. Microgrid for Remakri region-1 can cover 4000 people of Remakri and 500 people from Tindu. Remakri region 1 can cover about total 4500 people. Total primary load for Remakri region-1 is about 2.327MWh/d and $196.878 \mathrm{KW}$ peak. For $196.878 \mathrm{KW}$ power supplies three CSP plant and one biogas power plant have to be considered.

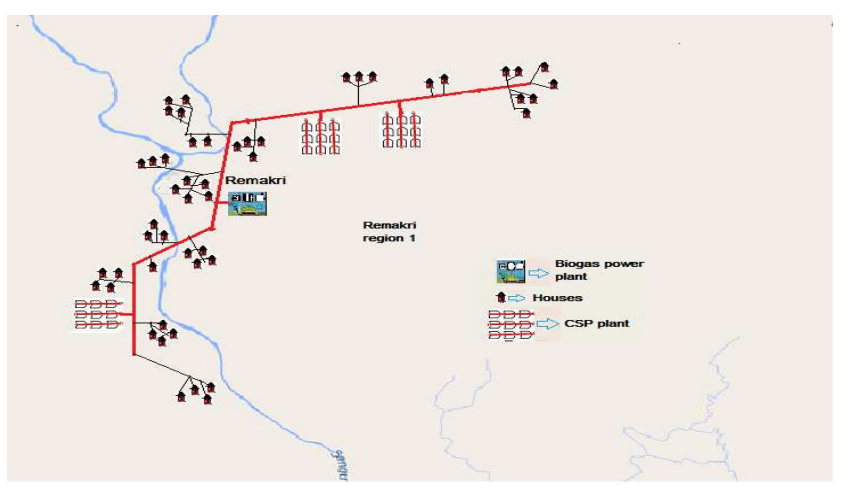

Figure 10. Microgrid design of Remakri region-1.

\subsection{Microgrid Connection Design for Remakri Region-2}

Total population of Remakri region-2 is about 3200.Total load for Remakri region 2 is $1.64 \mathrm{MWh} / \mathrm{d}$ and $139.36 \mathrm{KW}$ peak. For total 139.36 KW power supplies two CSP plant and one biogas have to be considered.

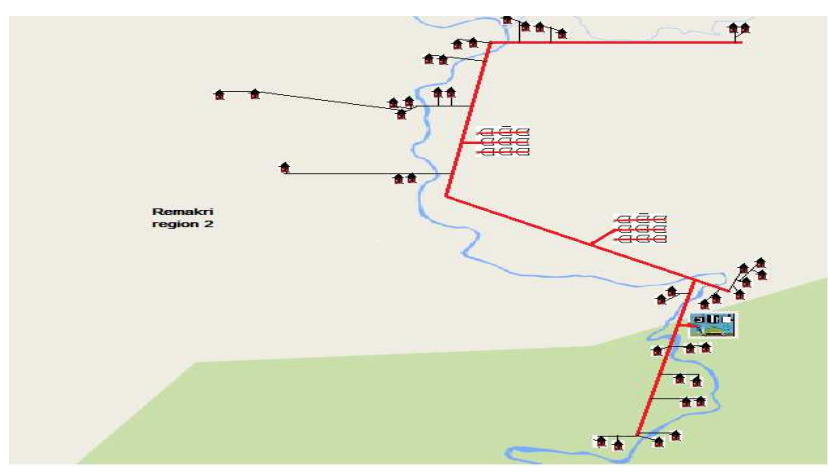

Figure 11. Microgrid design of Remakri region-2.

\section{Cost Calculation of CSP-Biogas Power Plant}

It is very important to understand the information of the relative costs and benefits of renewable energy technologies to arrive at an accurate assessment of most appropriate renewable technologies. Cost can be measure including financing cost, implement cost (solar reflectors, biogas plant), total installation cost, fixed and variable operation and maintenance costs.

\subsection{Cost Calculation of 60KW CSP Plant}

Initial cost of CSP plant is higher than fossile fuel plant. The initial cost of CSP plants approximately four-fifths of the total cost [14]. CSP plant with thermal energy storage is more expensive, but allowed higher capacity factors. The operation costs of CSP plants are lower than fossil fuel power plants. The operation and maintenance cost depend on replace mirrors and receiver, cost of mirror washing, etc. This microgrid system used 17 CSP plant. Each CSP plant has considered $60 \mathrm{KW}$ plant.

Table 6. $60 \mathrm{KW}$ CSP plant cost calculation by using RETScreen 4.

\begin{tabular}{lll}
\hline RETScreen Energy Model-Powerproject & \\
\hline $\begin{array}{l}\text { Proposed case power system } \\
\text { Technology }\end{array}$ & Solar thermal power & \\
$\begin{array}{l}\text { Solar thermal power } \\
\text { Power capacity }\end{array}$ & $60 \mathrm{KW}$ & \\
$\begin{array}{l}\text { Manufacturer } \\
\text { Model }\end{array}$ & & $\$ 300000$ \\
$\begin{array}{l}\text { Capacity factor } \\
\text { Electrcity exported to grid } \\
\text { MWh }\end{array}$ & $50 \%$ & \\
$\begin{array}{l}\text { Electricity exported rate } \$ \text { per } \\
\text { MWh }\end{array}$ & 263 & \\
\hline
\end{tabular}

According to the RETScreen 4 total installation cost for $60 \mathrm{KW}$ power plant is about $\$ 300000$. Operation annual cost for CSP plant can be between $0.02 \%-0.035 \%$ of total installation cost [15]. Here from RETScreen 4 the operation and maintenance cost is about $\$ 3000$. Electricity generation cost is about $\$ 0.10 / \mathrm{KWh}$. One $60 \mathrm{KW}$ CSP plant can generate upto $263 \mathrm{MWh}$ electricity per year that means 
$720.5 \mathrm{KWh}$ of electricity per day.

\subsection{Cost Calculation of 20KW Biogas Power Plant}

Cost of biogas power plant depends on cost of installation of plant, cost of maintenance, cost of combustion engine, etc. Total installation cost of a $20 \mathrm{KW}$ biogas power plant is about $\$ 63011[16]$. Generation cost of biogas power is about $\$ 0.11 / \mathrm{KWh}[17]$.

\section{Result Analysis}

The current generation cost of electricity in Bangladesh is about $\$ 0.079 / \mathrm{KWh}$ [18]. For gas based power plant cost varies from $\$ 0.062$ to $\$ 0.070 / \mathrm{KWh}[19]$ ]. In PV power plant generation cost is about $\$ 0.51 / \mathrm{KWh}$ [20]. Government purchases electricity at the rate of $\$ 0.29 / \mathrm{KWh}$ from Quick Rental Power Plant (QRPP)[21]. For CSP-biogas combined system, cost is found $\$ 0.10 / \mathrm{KWh}$ for CSP and $\$ 0.11 / \mathrm{KWh}$ for biogas power plant, which is better than PV plant and quick rental power plant. Fig. 12 shows the cost comparison.

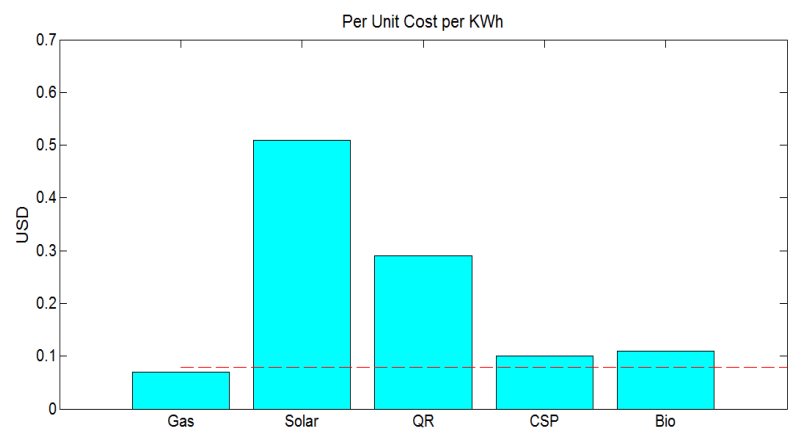

Figure 12. Cost comparison of CSP and biogas plant with other power plant.

\section{Conclusion}

The performance of CSP-biogas combined microgrid system is more economical. This microgrid system can be a great solution for removing electricity crises in rural and remote area of Bangladesh. Thanchi is a remote area and CSP-biogas combined microgrid can be very useful. Population density of Thanchi is not same in all areas. Some areas are highly density and some areas have no population. So cost of single microgrid is more for coverage total area. We have taken some population areas and proposed CSP-biogas combined microgrid system. But for implementation of this project some suitable places have to be selected for installation CSP and biogas power plant.

\section{Acknowledgment}

Authors would like to thank American International University Bangladesh (AIUB) for their financial and logistical support and for providing necessary guidance.

\section{References}

[1] Bangladesh Energy Situation - energypedia.info.

[2] Expanding Renewable Energy in Bangladesh - CLIMATE HIMALAYA.

[3] K. Anam, H. A. Bustam, "Power Crisis \& Its Solution Through Renewable Energy in Bangladesh," in Multidisciplinary Journal in Science and Technology, September edition, 2011.

[4] https://en.wikipedia.org/wiki/Biogas.

[5] Bangladesh National information window. Bangladesh.gov.bd.

[6] RETScreen plus software "Climate database".

[7] Agriculture Census 2008.

[8] D. Kruger,A. Kenissi, S. Dieckmann, C. Bouden, A. Baba, A. oliveira, H. Soares, E. Rojas Bravo, R. Ben cheikh, F. Orioli, D. Gasperini, K. Hennecke, H. Schenk, "Pre-Design of a Mini CSP plant"International Conference on Concentrating Solar Power and Chemical Energy System, Solar PACES 2014.

[9] Leonel Reyes Ochoa "Engineering Aspects of a Parabolic Though Collector Field with Direct Steam Generation and Organic Ranking Cycle" Cologne, Germany, October 2014.

[10] A model biogas plant that produce 320 units of power a day.

[11] How much methane does a cow produce in one day.

[12] Standards/Manual/guidelines for small hydro development, ministry of new and renewable energy govt. of India, June 2011.

[13] Off grid mapping of Bangladesh using gis tools.

[14] IRENA "RENEWABLE ENERGY TECHNOLOGIES: COST ANALYSIS SERIES".

[15] RENEWABLE ENERGY TECHNOLOGY: COST ANALYSIS SERIES, Volume 1: Power sector Issue 2/5, June 2012.

[16] THE HINDU, http://www.thehindu.com/todays-paper/tpnational/tp-karnataka/a-model-biogas-plant-that-produces320-units-of-power-a-day/article3879626.ece.

[17] RETScreen International $50 \mathrm{~kW}$ - Biogas / Canada.

[18] The Daily Star "Power utility press for big hike in tariff".

[19] Mustafa, K. Mujeri, Tahreen Tahrima Chowdhury, "Quick Rental Power Plants in Bangladesh: An Economic Appraisal," Bangladesh Institute of Development Studies, June 2013.

[20] RETScreen International Power-Photovoltaic$1000 \mathrm{kw} /$ Germany.

[21] Quick Rental power plant project failing in Bangladesh, https://bangladeshstudies.wordpress.com/2012/04/23/quickrental-power-plant-project-failing-in-bangladesh/. 